„Analecta Cracoviensia” 50 (2018), s. 53-77

DOI: http://dx.doi.org/10.15633/acr.3283

ks. Mirosław Kiwka

Papieski Wydział Teologiczny we Wrocławiu

\title{
Evelyn Underhill rozumienie mistyki
}

Wbrew pozorom nie tylko w naszej epoce termin „mistyka” budzi wiele kontrowersji. Już na początku ubiegłego stulecia William James pisał w uchodzącym dziś za klasyczne dziele Doświadczenia religijne (Varieties of Religious Experience): „Wyrazy «mistycyzm» $\mathrm{i}$ «mistyczny» często bywają używane w znaczeniu nagannym; przymiotnikiem tym oznaczamy mniemanie, które uważamy za niejasne, mgliste, sentymentalne i na niczym logicznym nie oparte. Dla niektórych pisarzy mistyk to taki człowiek, który wierzy w oddziaływanie myśli na odległość lub powracanie duchów. Wyraz ten używany w taki sposób posiada wartość niewielką: istotnie mało jest wyrazów równie wieloznacznych”.

Tę opinię zdaje się podzielać również Evelyn Underhill (1875-1941)², autorka wielu książek i artykułów o życiu religijnym człowieka ${ }^{3}$, wybitna znawczyni

1 W. James, Doświadczenia religijne, tłum. J. Hempel, Kraków 2001, s. 292.

2 Spośród wielu publikacji omawiających życie i twórczość Evelyn Underhill na uwagę zasługują następujące: M. Cropper, The Life of Evelyn Underhill, New York 1958; C. J. R. Armstrong, Evelyn Underhill (1875-1941). An Introduction to Her Life and Writings, Grand Rapids 1976; M. Ramsey, A. M. Allchin, Evelyn Underhill. Two Centenary Essays, Oxford 1977; A. Callahan, Evelyn Underhill: Spirituality for Daily Living, Lanham 1997; D. Greene, Evelyn Underhill: Artist of the Infinite Life, Notre Dame 1998. W miarę obszerną bibliografię opracowań na temat życia i twórczości Underhill można znaleźć między innymi w: Evelyn Underhill: Modern Guide to the Ancient Quest for the Holy, ed. D. Greene, Albany 1988, s. 219-224. W Stanach Zjednoczonych istnieje Stowarzyszenie Evelyn Underhill, które w swoich założeniach ma zadanie gromadzenia publikacji na jej temat. Zob. http://www.evelynunderhill.org (7.08.2017).

3 Do najważniejszych dzieł Underhill o tematyce religijnej zalicza się następujące: Mysticism: A Study of the Nature and Development of Man's Spiritual Consciousness (1911); The Path of Eternal Wisdom. A Mystical Commentary on the Way of the Cross (1911); The Spiral Way. Being a Meditations upon the Fifteen Mysteries of the Soul's Ascent (1912); The Mystic Way. A Psychological Study 
duchowości i jedna ze prominentnych postaci anglikanizmu pierwszej połowy xx wieku4. W wydanym w roku 1911 dziele Mysticism. The Nature and Development of Spiritual Consciousness Underhill pisała między innymi, że przymiotnik „mistyczny” używany jest na tak wiele różnych sposobów, iż mało doświadczony czytelnik może odnieść wrażenie, że zawiera on w sobie jakąś mętną ideę, dotyczącą przeróżnych teorii i praktyk pozostających w bliżej niesprecyzowanej relacji do tego, co w jakiś sposób wymyka się zmysłom. Słowem tym określa się zarówno ekstazy świętych, jak i okultystyczne poczynania, czary oraz marzycielską poezję, modlitwę i chiromancję, doktrynalne wybryki gnostycyzmu i chłodne spekulacje filozofów wątpliwej reputacji ${ }^{5}$. Gdyby do tej listy wymienionych przez nią znaczeń dodać jeszcze opublikowane w latach 50. ubiegłego wieku rozważania Aldousa Huxleya o pseudomistycznych przeżyciach wywołanych meskaliną Czy LSD ${ }^{6}$, wyczerpalibyśmy zapewne zasób możliwości semantycznych słowa „mistyka”. Prowadząca swoje badania niemal od początków współczesnej teorii mistyki Underhill widziała naglącą potrzebę określenia w miarę jasnych kryteriów, które umożliwiłyby odróżnienie autentycznych doświadczeń mistycznych od fenomenów przybierających jedynie ich pozory ${ }^{7}$. Postulat ten pomimo upływu czasu do dziś nie utracił nic ze swojej aktualności. Pytania, jakie w tym kontekście pojawiają się na początku XXI wieku, nie różnią się nazbyt od stawianych na progu ubiegłego stulecia, dlatego poznanie wówczas udzielonych odpowiedzi może służyć pomocą w rozwiązaniu wielu współczesnych kontrowersji dotyczących doświadczenia mistycznego. Stąd też w niniejszym artykule zajmiemy się omówieniem zasadniczych zrębów teorii mistyki, jakie wyłaniają się z najważniejszych dzieł Underhill.

of Christian Origins (1913); Practical Mysticism: A Little Book for Normal People (1914); Ruysbroeck (1915); The Essentials of Mysticism and other Essays (1920); The Life of the Spirit and the Life of Today (1922); The Mystics of the Church (1925); Concerning the Inner Life (1926); Man and the Supernatural. A Study in Theism (1927); The House of the Soul (1929); The Light of Christ (1932); The Golden Sequence. A Fourfold Study of the Spiritual Life (1933); Worship (1936); The Spiritual Life (1937); The Mystery of Sacrifice. A Study on the Liturgy (1938); Abba. A Meditation on the Lord's Prayer (1940). Kompletną bibliografię pism Underhill można znaleźć w między innymi w: Evelyn Underhill: Modern Guide..., dz. cyt., s. 224-256.

4 Od 2000 roku Kościół anglikański wspomina ją liturgicznie 15 czerwca.

5 Por. E. Underhill, Mysticism. The Nature and Development of Spiritual Consciousness, Oxford 2002, s. 72; E. Underhill, The Mystics of the Church, Cambridge 1925, s. 9.

6 Swoje doświadczenia Huxley opisał w zbiorach esejów: The Doors of Perception (1954) oraz Heaven and Hell (1956).

Por. E. Underhill, Mysticism, dz. cyt., s. 72. 


\section{Problem definicji mistyki}

Podejmując próbę określenia natury mistyki, Underhill zauważa, że jej istotnym elementem pozostanie zawsze wszechogarniająca świadomość istnienia Boga oraz duszy ludzkiej zdolnej do życia w osobowej komunii z Nim ${ }^{8}$. W sensie historycznym i psychologicznym mistyka jest intuicyjnym doświadczeniem Boga, bezpośrednim doświadczeniem Jego obecności ${ }^{9}$.

$\mathrm{W}$ aspekcie poznawczym Underhill ujmuje mistykę w kategoriach wiedzy o tym, co fundamentalne i ostateczne. Podkreślając zaś wymiar funkcjonalny mistyki, określa ją mianem sztuki wchodzenia w świadomą relację z Absolutem $^{10}$. W tej perspektywie mistyk to osoba, która poznanie Boga posiadła nie tyle na zasadzie akceptacji uznanego kanonu wierzeń religijnych, ile w sposób bezpośredni i bardzo osobisty ${ }^{11}$, która w jakimś stopniu doszła do praktycznego z Nim zjednoczenia ${ }^{12}$ lub też stawiając je sobie za cel, jest przekonana o możliwości jego osiągnięcia ${ }^{13}$. Mistyk to nie tylko człowiek, którego cechuje bojaźń Boża i ogromne pragnienie Absolutu, mistyk - zdaniem Underhill - to także natura zdolna do nadzwyczajnej koncentracji, wzniosłych odczuć moralnych i artystycznej wrażliwości ${ }^{14}$.

Rozumienie mistyki u Underhill obejmuje po pierwsze praktyczną edukację ducha, której celem jest doprowadzenie do stanu doskonałej harmonii z tym, co wieczne, do życia w jedności z Bogiem. Po drugie, wiąże się z przekonaniem

8 „We will begin, then, with the central fact of the mystic's experience. This central fact, it seems to me, is an overwhelming consciousness of God and of his own soul a consciousness which absorbs or eclipses all other centers of interest. [...] Hence we must put first among our essentials the clear conviction of a living God as the primary interest of consciousness and of a personal self capable of communion with Him" (E. Underhill, The Essentials of Mysticism, w: Understanding Mysticism, ed. by R. Woods, Garden City 1980, s. 27).

9 Por. E. Underhill, The Mystics of the Church, dz. cyt., s. 9.

${ }^{10}$ „[...] the art of establishing conscious relation with the Absolute” (E. Underhill, Mysticism, dz. cyt., s. 81).

${ }_{11}$ Por. E. Underhill, The Mystics of the Church, dz. cyt., s. 10.

${ }^{12}$ „Mysticism in its pure form, is the science of ultimates, the science of union with the Absolute, and nothing else, and that the mystic is the person who attains to this union, not the person who talks about it” (E. Underhill, Mysticism, dz. cyt., s. 72).

${ }^{13}$ "Mysticism is the art of union with Reality. The mystic is a person who has attained that union in greater or less degree; or who aims at and believes in such attainment" (E. Underhill, Practical Mysticism, New York 1915, s. 3).

${ }^{14}$ Por. E. Underhill, Mysticism, dz. cyt., s. 91; E. Underhill, The Mystic as Creative Artist, w: Understanding Mysticism, dz. cyt., s. 400-414. 
o istnieniu poza światem materialnym także świata duchowego. W pierwszym przypadku mistyka jest kwestią czystego doświadczenia, w drugim zaś intuicji i wiary ${ }^{15}$.

\section{Znaki, zasady i noty}

W swojej twórczości pisarka dąży nie tyle do sformułowania błyskotliwej i wyczerpującej definicji mistyki, ile raczej do obszernej analizy, której efektem byłoby określenie zespołu cech charakteryzujących mistykę w sposób możliwie najpełniejszy. Realizując taki zamiar, odwołuje się najpierw do analogicznych dokonań Jamesa, uznając je za niewystarczające ${ }^{16}$.

Dla przypomnienia: Willam James we wspomnianej już książce pt. Doświadczenia religijne zaproponował cztery znaki (marks) mistycznych stanów świadomości: niewyrażalność, zdolność poznawczą, nietrwałość i bierność ${ }^{17}$. Ich istotę wyjaśniał w następujący sposób:

- niewyrażalność (ineffability)

„Najdogodniejszy znak, który pozwala zaliczyć jakiś stan do kategorii mistycznej, jest negatywny. Człowiek podlegający temu stanowi powiada, że zupełnie nie daje on się wyrazić, że treści jego niepodobna całkowicie wypowiedzieć słowami. Wynika stąd, że właściwości tego stanu mogą być tylko doznane bezpośrednio i nie mogą być udzielane lub przekazywane innym. Pod tym względem stany mistyczne są bardziej podobne do stanów uczuciowych niż do stanów intelektualnych. Nie można wyjaśnić jakości i wartości jakiegoś uczucia komuś, kto nigdy go nie doznawał. Aby znać wartość symfonii, trzeba mieć ucho muzykalne, aby zrozumieć stan duchowy kochanka, trzeba było kochać się samemu. Komu brak serca lub ucha, ten nie może należycie rozumieć muzyka czy kochanka i bliski jest uważania go za człowieka słabego umysłowo lub zgoła głupiego. Mistyk zwykle jest zdania, że większość $\mathrm{z}$ nas odnosi się do jego doświadczeń w sposób równie niekompetentny"18.

${ }^{15}$ „Mysticism, then, will here be identified, first, with that practical education of the spirit which was the art of the great mystics of the past, and which leads to the condition of perfect harmony with the eternal world which they call the «unitive life»; and, secondly, with a belief in, and realization of, that spiritual world behind the world of the senses, which those mystics describe to us [...]. In the one case, it is a matter of pure experience; in the other of intuition and faith" (E. Underhill, Future of Mysticism, w: Evelyn Underhill: Modern Guide..., dz. cyt., s. 63).

${ }_{16}$ Por. E. Underhill, Mysticism, dz. cyt., s. 81.

${ }_{17}$ Por. W. James, Doświadczenia religijne, dz. cyt., s. 293-294.

18 W. James, Doświadczenia religijne, dz. cyt., s. 293. 
- wartość poznawcza (noetic quality)

„Stany mistyczne, jakkolwiek tak podobne do stanów uczuciowych, w oczach doznających ich wydają się jednocześnie stanami poznania. Są to stany wejrzenia w głębię prawdy, niedostępnej dla intelektu rozważającego. Pomimo swej niewyrażalności są to pełne znaczenia i wagi rozjaśnienia tajemnic i objawienia; i przyjąć można za prawidło, że pozostawiają po sobie ciekawe poczucie swego autorytetu"19.

- nietrwałość (transiency)

„Stany mistyczne są niemożliwe do zniesienia przez czas dłuższy. Z wyjątkiem przypadków rzadkich trwają po pół godziny; dwie godziny zdaje się tu być zupełnym krańcem, poza którym stan mistyczny blednie w zwykłym świetle dziennym. Nieraz po tym wyblaknięciu własności jego tylko niedokładnie dają się odtworzyć w pamięci; gdy jednak stan powróci, natychmiast jest rozpoznany; i od jednego pojawienia się do drugiego może rozwijać się nieprzerwanie - stając się coraz bogatszym wewnętrznie i coraz większe zdobywając sobie znaczenie" ${ }^{20}$.

- bierność (passivity)

„Osiąganie stanu mistycznego może być ułatwione przez rozmyślne czynności przygotowawcze - przez skupienie na nim uwagi, za pomocą pewnych ćwiczeń cielesnych lub innymi drogami wskazanymi w podręcznikach mistycznych; skoro jednak pewien znamienny rodzaj świadomości doprowadził już do stanu mistycznego, mistyk odczuwa, że jego własna wola jest jakby w zawieszeniu, wydaje mu się, jak gdyby był pochwycony i podtrzymywany przez jakąś potęgę wyższą. Ta ostatnia właściwość łączy stany mistyczne z pewnymi określonymi zjawiskami wtórnej lub rozdwojonej osobowości, jak np. mowa prorocza, pismo automatyczne lub transy mediumiczne. Te ostatnie stany jednak tym różnią się od mistycznych, że choćby najpełniej były rozwinięte, mogą zupełnie nie pozostawiać po sobie wspomnień, a wobec tego przechodzą bez wpływu na życie wewnętrzne doznającego je osobnika, czyniąc tylko przerwy w jego życiu. Natomiast stany mistyczne, w znaczeniu ścisłym, nigdy nie są samymi przerwami. Zawsze pozostaje coś z nich w pamięci wraz z poczuciem ich wagi. Zmieniają one normalne życie wewnętrzne doznającego ich podmiotu. W dziedzinach tych jednak trudno o rozróżnienie ścisłe i natrafiamy na najrozmaitsze stopniowania i pomieszania”21.

\footnotetext{
19 W. James, Doświadczenia religijne, dz. cyt., s. 293.

${ }^{20}$ W. James, Doświadczenia religijne, dz. cyt., s. 293.

${ }^{21}$ W. James, Doświadczenia religijne, dz. cyt., s. 293-294.
} 
Underhill proponuje uzupełnienie „znaków” Jamesa opracowanymi przez siebie następującymi „zasadami” (rules, notes):

A. „Mistyka dotyczy praktyki, a nie teorii” ${ }^{\prime 2}$.

„Prawdziwa mistyka jest czymś aktywnym i praktycznym, a nie biernym i teoretycznym. Jest ona procesem życiowym, czymś, co angażuje człowieka we wszystkich wymiarach jego egzystencji. Nie jest natomiast jakąś teorią ${ }^{\prime 23}$. Ta zasada znalazła swoje zastosowanie w bardzo prostym określeniu mistyki, jakie autorka zamieściła we wstępie do książki The Mystics of the Church: mistyka to „życie, którego celem jest zjednoczenie z Bogiem ${ }^{24}$. Właśnie terminy „życie”, „cel”, „zjednoczenie” jej zdaniem bardzo dobrze oddają egzystencjalny, aktywny i zgoła nie-teoretyczny charakter mistyki. Samo stwierdzenie, że mistyka w swej istocie jest praktyką, a nie teorią, nie wyklucza oczywiście możliwości teoretyzowania na jej temat. Jednakże z dość oczywistym zastrzeżeniem, że każda teoria pozostaje zawsze wobec konkretnego doświadczenia czymś dalekim, pozbawionym życia i wtórnym. Dla wyrażenia tej prawdy Underhill posługuje się analogią, w której relacja pomiędzy doświadczeniem mistycznym a wykoncypowaną na jego podstawie teorią została oddana przez stosunek pomiędzy objawieniem a teologią. Mistyka, podobnie jak objawienie, jest przeżyciem osobowym w najbardziej intensywnej formie, doświadczeniem „zespalającym w jeden akt miłość i najwyższe poznanie"25. Jako taka staje się materiałem do konstruowania różnych interpretujących ją teorii, podobnie jak objawienie, fakt empiryczny, staje się przedmiotem namysłu teologicznego, w którym dokonuje się jego systematyzacji i interpretacji, nadając mu postać jakiegoś $\mathrm{credo}^{26}$. Jednakże sama znajomość teorii, choćby najbardziej prawdziwej i pociągającej, nie czyni jeszcze nikogo mistykiem, podobnie jak sama znajomość zasad muzyki oraz teorii gry na fortepianie nie sprawia, że szczęśliwego posiadacza tejże wiedzy już można uznać za pianistę. Wielcy mistycy - zauważa pisarka mówią nam nie tyle o swoich dociekaniach i spekulacjach, ile raczej o swoim konkretnym działaniu i przeżywaniu. Owszem, w wielu przypadkach ich przeżycia mogą stać się, i de facto stają się, przedmiotem teoretycznej

${ }^{22}$ „Mysticism is practical, not theoretical” (E. Underhill, Mysticism, dz. cyt., s. 82).

${ }^{23}$ E. Underhill, Mysticism, dz. cyt., s. 81.

${ }^{24}$ „[...] the life which aims at union with God" (E. Underhill, The Mystics of the Church, dz. cyt., S. 20).

25 E. Underhill, Mysticism, dz. cyt., s. 84.

${ }^{26}$ Por. E. Underhill, Mysticism, dz. cyt., s. 82. 
refleksji lub pełnej poetyckich metafor narracji, ale nawet w takiej formie pozostaną zawsze czymś wtórnym tak w stosunku do samego doświadczenia, jak i w relacji do rzeczywistości, której doświadczyli ${ }^{27}$. Najbardziej adekwatna interpretacja doświadczenia mistycznego dokonuje się tylko od wewnątrz. Tylko mistycy są w stanie najprawdziwiej pisać o mistyce. Wszyscy inni, opierając się na ich świadectwie i uwzględniając przy tym pozostawioną przez nich interpretację, mogą jedynie dedukować pewne wnioski ${ }^{28}$.

B. „Mistyka jest aktywnością całkowicie duchową"29.

„Cele mistyki są całkowicie transcendentne i duchowe. W żaden sposób nie zajmuje się ona dodawaniem czegokolwiek, badaniem, zmienianiem lub reformowaniem widzialnego świata. [...] Jednakże mistyk, wbrew opinii swoich przeciwników, nie zaniedbuje swych powinności wobec innych, chociaż swym sercem jest zawsze zwrócony ku Niezmiennemu" ${ }^{30}$. Formułując tę zasadę, Underhill wykluczyła z pojęcia mistyki wszelkie czynności magiczne, nawet te najbardziej wysublimowane i najmniej materialne w swoich przejawach ${ }^{31}$. Mistyka i magia to według niej fundamentalne i zarazem wykluczające się postawy wobec rzeczywistości duchowej. Odpowiadają im dwie odwieczne pasje człowieka: pragnienie miłości i pragnienie poznania. Każda z nich wyraża ów głód serca i intelektu za prawdą ostateczną. Mają więc one charakter praktyczny i empiryczny. Underhill w dużym uproszczeniu stwierdza, że istotą postawy związanej z magią jest „branie”, do natury zaś mistyki przynależy „dawanie”32. Magia, stawiając poznanie ponad miłość,

${ }^{27}$ Por. E. Underhill, Mysticism, dz. cyt., s. 82-84. Podobne spostrzeżenia zamieścił James już na wstępie swoich rozważań o mistyce, gdzie z całą pokorą napisał: „Czy moje traktowanie stanów mistycznych rzuci na nie światło lub zaciemni je, nie wiem, ponieważ natura moja stawia mnie poza nimi, czyli że mówię o nich tylko z drugiej ręki” (W. James, Doświadczenia religijne, dz. cyt., S. 292).

${ }^{28}$ Por. E. Underhill, Mysticism, dz. cyt., s. 49.

29 „Mysticism is an entirely spiritual activity” (E. Underhill, Mysticism, dz. cyt., s. 84).

$3^{30}$ E. Underhill, Mysticism, dz. cyt., s. 81.

${ }^{31}$ Autorka poświęca zagadnieniu magii relatywnie dużo miejsca. Ma to swoje uzasadnienie między innymi w jej osobistych doświadczeniach i fascynacjach, gdyż we wczesnym okresie swoich poszukiwań duchowych była związana $z$ odwołującą się do tradycji różokrzyżowców, ezoteryczną organizacją Golden Dawn (Hermetyczny Zakon Złotego Brzasku). Z tego okresu zainteresowań okultyzmem wyniosła przekonanie o wpływie magii na religię, jej atrakcyjności i zagrożeniach. Owocem tych poszukiwań był opublikowany przez nią w 1907 roku tekst pt. Defense of Magic, w: Evelyn Underhill: Modern Guide..., dz. cyt., s. 31-46. Prezentowane tam przekonania uległy później stopniowej ewolucji, co widać już w opublikowanym w 1911 roku dziele Mysticism (s. 149-164).

${ }^{32}$ Por. E. Underhill, Mysticism, dz. cyt., s. 70. 
dąży do zdobycia wiedzy o tym, co ponadzmysłowe. Jest w tym bardzo indywidualistyczna i zachłanna. Stara się zawładnąć światem duchowym i wykorzystać go do swoich własnych celów, wpływając na to, co widzialne, za pomocą tego, co niewidzialne. Mistyk natomiast, w przeciwieństwie do szamana, nigdy nie stara się korzystać z przywileju, jaki daje mu wobec innych jego doświadczenie. Chociaż bywa postrzegany właśnie jako swego rodzaju reprezentant Wszechmocnego, to jednak nie przejawia ambicji zawładnięcia Jego wszechwiedzą czy wszechmocą. Doświadczenie komunii z Bogiem wycisza w nim wszystkie inne pragnienia. Posiadając Boga i będąc przez Niego posiadanym, nie potrzebuje już niczego więcej. Jako uczestnik wieczności zaledwie toleruje swoje uwikłanie w czasoprzestrzen ${ }^{33}$.

C. „Celem i drogą mistyki jest miłość”34.

„Jedyny Bóg jest dla mistyka nie tylko metafizycznym fundamentem wszystkiego, co istnieje, ale także żywym i osobowym Przedmiotem miłości, nigdy natomiast nie stanowi dla niego przedmiotu eksploracji" ${ }^{35}$.

Powyższe stwierdzenie Underhill uważa za centralną zasadę, spośród wszystkich dotychczas wymienionych. W jej świetle Bóg jawi się nie tylko jako bytowa podstawa wszystkiego, co istnieje (Absolut, Nieskończoność, Wieczność), lecz nade wszystko jako osoba, z którą nawiązuje się jedyną i niepowtarzalną relację, stanowiącą swoistą syntezę pragnienia, tęsknoty, wyrzeczenia, ofiary, cierpienia, zawierzenia, oddania i wreszcie zjednoczenia. Underhill nieustannie podkreśla, że sercem mistyki jest bezinteresowna miłość, rozumiana jako duchowa siła ciążenia ${ }^{36}$ i najbardziej radykalny wyraz witalnych dążeń jednostki. Owa bezinteresowna miłość sprawia, że mistyczna relacja z Bogiem staje się związkiem oblubieńczym, gdzie Bóg jest jedynym celem wszelkich dążeń człowieka. Całe fragmenty pism mistyków przenika ów żar intymnej i płomiennej miłości ku Stwórcy, czyniąc z mistyki swego rodzaju „wiedzę serca” (a science of heart) ${ }^{37}$, wyraz płomiennej pasji skierowanej ku realnie istniejącej osobie ${ }^{38}$. Wszystkie jednostkowe doświadczenia mistyczne mają swój sens jedynie jako etapy

33 Por. E. Underhill, Mysticism, dz. cyt., s. 84-85.

34 „The business and method of mysticism is love” (E. Underhill, Mysticism, dz. cyt., s. 85).

35 E. Underhill, Mysticism, dz. cyt., s. 81.

${ }^{36}$ Więcej o miłości jako mistycznej sile ciążenia zob. np. M. Kiwka, Mistyczne implikacje Arystotelesowskiej koncepcji miejsca naturalnego, „Wrocławski Przegląd Teologiczny” 2014 nr 2, s. 7-19.

37 E. Underhill, Mysticism, dz. cyt., s. 89.

${ }^{38}$ Por. E. Underhill, Mysticism, dz. cyt., s. 85-90. 
rozwoju miłości oblubieńczej. Mistyka znajduje w miłości swoją rację i ostateczne uzasadnienie. Logika miłości sprawia, że mistyk nie dąży, nawet teoretycznie, do innych celów (np. poznanie, moc, władza), poza bezwarunkowym przylgnięciem do Boga, który sukcesywnie wypełnia cały jego horyzont życiowy, dokonując stopniowego i konsekwentnego przeobrażenia wszystkich sfer jego istnienia.

D. „Mistyka wiąże się z określonym doświadczeniem psychicznym”39. Stan zjednoczenia z Bogiem, który jest jedynym celem mistycznej przygody, niesie ze sobą nową, bogatszą formę istnienia. Ta nowa forma istnienia ujawnia się i nabiera kształtów w trakcie procesu dojrzewania, którego skutkiem jest uwolnienie nowego poziomu świadomości ${ }^{40}$. Przemiana świadomości przebiega - zdaniem Underhill - w dwóch różnych kierunkach. Pierwszym jest uświadomienie sobie nieskończonej doskonałości Absolutu. Drugi natomiast polega na wewnętrznej przemianie, ku której ta świadomość absolutnej doskonałości Boga przynagla i mobilizuje ${ }^{41}$. Innymi słowy, warunkiem zjednoczenia $\mathrm{z}$ Bogiem jest nie tylko transformacja moralna i duchowa człowieka, lecz również przemiana psychologiczna, która polega na otrzymaniu w mistycznym darze nowego rodzaju świadomości. Właśnie tenże dar, jak się wydaje, stanowi istotę owego „doświadczenia psychicznego”, o którym pisze Underhill ${ }^{42}$.

E. „Prawdziwa mistyka nigdy nie poszukuje samej siebie” ${ }^{43}$.

Tę ostatnią zasadę Underhill formułuje jako logiczną konsekwencję i zarazem syntezę czterech wcześniejszych. W komentarzu do niej po raz kolejny podkreśla, że mistyka nie jest, jak wielu myśli, pogonią za nadprzyrodzonymi radościami i spełnieniem wielkich ambicji człowieka. Mistyk nie wyrusza

39 „Mysticism entails a definite psychological experience” (E. Underhill, Mysticism, dz. cyt., s. 90).

${ }^{40}$ Por. E. Underhill, Mysticism, dz. cyt., s. 81. Więcej na temat świadomości mistycznej zob. np. M. Kiwka, Mistycyzm integralny w ujęciu Bernarda McGinna, „, Roczniki Filozoficzne” 1 (2017), s. $34-37$.

${ }^{41},[\ldots]$ the full mystic consciousness is extended in two distinct directions. So too there are two distinct sides to the full mystical experience. (A) The vision or consciousness of Absolute Perfection. (B) The inward transmutation to which that Vision compels the mystic, in order that he may be to some extent worthy of that which he has beheld: may take his place within the order of Reality. He has seen the Perfect. he wants to be perfect too" (E. Underhill, Mysticism, dz. cyt., s. 90).

${ }^{42}$ Por. E. Underhill, Mysticism, dz. cyt., s. 90-92.

43 „True mysticism is never self-seeking” (E. Underhill, Mysticism, dz. cyt., s. 92). 
na poszukiwanie visio beatifica, ekstatycznego zjednoczenia czy też jakiejś innej formy osobistego samospełnienia. Prawdziwi mistycy nie oczekują nagrody ani nie stawiają warunków. Nigdy nie ustają w poszukiwaniu Boga, które uważają za swoją najwyższą powinność. Pełnia miłości przychodzi razem $\mathrm{z}$ całkowitym zapomnieniem o sobie. Paradoksalnie kontemplatycy znajdują siebie, zatraciwszy się zupełnie w miłości ${ }^{44}$.

Wyróżnione przez Underhill „zasady” w niczym nie przeczą „znakom” Jamesa. „Zasady” Underhill tworzą dla „znaków” Jamesa perspektywę, w której te ostatnie nabierają większej wyrazistości. Mistyka wyłania się z nich jako swego rodzaju umiejętność, która stopniowo nabiera kształtów w ramach duchowego procesu zmierzającego ku coraz to wyższym poziomom rzeczywistości, a w konsekwencji ku coraz to ściślejszemu utożsamieniu się z Nieskończonym. Dopiero w tym kontekście wymienione przez Jamesa niewyrażalność, zdolność poznawcza, nietrwałość, bierność zyskują pełniejszy sens, stając się wyznacznikami dynamiki całości.

\section{Proces mistyczny i jego etapy}

Kategoria procesu wydaje się niezwykle przydatna do wyrażenia istoty i natury mistyki. Celem procesu mistycznego jest stworzenie takich warunków, w których możliwe staje się świadome i trwałe zjednoczenie z Bogiem. Zmierzając ku temu zjednoczeniu, mistyk przechodzi przez kolejne etapy rozwoju, tworzące jego mistyczną drogę. Najogólniej mówiąc, pod pojęciem „mistycznej drogi” (mystic way) Underhill rozumie „proces sublimacji, który wynosi relację ludzkiego «ja» do uniwersum na poziom wyższy niż ten, na którym zwykle funkcjonuje normalna świadomość człowieka"45. Składają się nań wewnętrzne dyspozycje i konkretne działania. Ponieważ poszczególne etapy tego procesu dają się w pewien sposób wyróżnić i zdefiniować, można je $\mathrm{z}$ powodzeniem odnaleźć i porównać u każdego z mistyków. Na podstawie wielości świadectw, niezależnie od ich uwarunkowań historycznych i geograficznych, da się opisać jakąś wspólną dla wszystkich psychologię procesu mistycznego. Zdaniem Underhill fakt ten przemawia za obiektywnym charakterem rzeczywistości

${ }^{44}$ Por. E. Underhill, Mysticism, dz. cyt., s. 92-94.

45 „The mystic way is best understood as a process of sublimation, which carries the correspondences of the self with the Universe up to higher levels than those on which our normal consciousness works" (E. Underhill, The Essentials of Mysticism, dz. cyt., s. 29). 
będącej przedmiotem doświadczenia mistycznego. Stanowi on również ważki argument przemawiający za substancjalną jednością procesu mistycznego ${ }^{46}$.

Zastanawiając się nad zagadnieniem podziału procesu rozwoju życia duchowego na poszczególne etapy, autorka podkreśla, że każdy zabieg klasyfikacji jest ostatecznie jakimś mniej lub bardziej uprawomocnionym uogólnieniem. W związku z tym zaproponowana przez nią systematyzacja nie powinna być traktowana jako coś nieprzekraczalnego i obowiązującego wszystkich jednakowo. W jednym ze swoich dzieł wymienia ona pięć zasadniczych etapów procesu rozwoju mistycznego ${ }^{47}$ :

A. Przebudzenie (awakening), polegające na uświadomieniu sobie boskiego wymiaru rzeczywistości. Etapowi temu towarzyszy zwykle intensywne uczucie radości i uniesienia.

B. Oczyszczenie (purgation) - stan bólu i wysiłku, polega na dostrzeżeniu kontrastu pomiędzy boskim pięknem a własną niedoskonałością. Poznanie to prowadzi do dyscypliny i umartwień, czyli wysiłku związanego z eliminacją przeszkód na drodze do zjednoczenia.

C. Oświecenie (illumination) - następuje, gdy oczyszczenie duszy doprowadziło do wyzbycia się przywiązania do rzeczywistości zmysłowej, rozwoju cnót i powrotu radosnego przeżywania obecności Boga. Underhill określa oświecenie stanem kontemplacji par excellence.

D. Śmierć mistyczna (mystic death) - ostateczne i całkowite oczyszczenie, zwane także "cierpieniem mistycznym” (mystic pain), „nocą duszy” (dark night of the soul) lub "ukrzyżowaniem duchowym” (spiritual crucifixion). Wiąże się z utratą odczuwania obecności Bożej i wielkiego opuszczenia. Etap ten prowadzi do oczyszczenia woli z osobistych pragnień oraz do zupełnego poddania i bierności.

E. Zjednoczenie (union) - jedyny i ostateczny cel mistycznej drogi. Jest stanem życia czysto duchowego, pełnym równowagi i spokojnej radości, wewnętrznej siły i intensywnej pewności. Nie należy go, zdaniem Underhill, utożsamiać z ekstazą. Zjednoczenie bowiem w przeciwieństwie do ekstazy jest stałym przebywaniem na transcendentnych poziomach rzeczywistości. W żargonie mistyków bywa ono wyrażane za pomocą symboli mistycznych zaślubin i przebóstwienia.

${ }^{46}$ Por. E. Underhill, Mysticism, dz. cyt., s. 91-92.

47 Por. E. Underhill, Mysticism, dz. cyt., s. 169-170. Dokładnemu omówieniu poszczególnych etapów Underhill poświęca drugą część swojego dzieła Mysticism, zatytułowaną The Mystic Way. 
Wyróżnione wyżej etapy można z powodzeniem sprowadzić do trzech klasycznych: oczyszczenia, oświecenia i zjednoczenia. Underhill wymienia je w książce The Mystics of the Church ${ }^{48}$, podobnie czyni w tekście The Essentials of Mysticism ${ }^{49}$. Tym sposobem autorka w kwestii struktury drogi mistycznej hołduje zasadniczo tradycji podziału trójczłonowego. Podział ten sięga swymi korzeniami aż do Orygenesa, który na podstawie egzegezy Księgi Przysłów, Koheleta oraz Pieśni nad Pieśniami określił trzy stopnie chrześcijańskiej wersji greckiej paidei, a mianowicie: wiedzę moralną, wiedzę naturalną i wiedzę kontemplacyjną. Uczeń i kontynuator myśli Orygenesa, Ewagriusz z Pontu, zaadaptował ów podział do opisu życia duchowego ojców pustyni, wyróżniając: praktike (życie ascetyczne) - oczyszczenie i uspokojenie umysłu; physike (kontemplacja stworzenia) - odsłanianie prawd ukrytych we wszystkich bytach; theologike (kontemplacja Boga) - odwrócenie się od rzeczy materialnych i zwrócenie się do ich Pierwszej Przyczyny, a w konsekwencji osiągnięcie istotowego poznania Trójcy Świętej. Klasyczne sformułowanie trójpodziału drogi mistycznej wyszło spod pióra Pseudo-Dionizego Areopagity około roku 500. W przedstawionej przez niego wizji procesu wstępowania (anagogia) droga ku Bogu wiedzie niezmiennie przez trzy stadia: oczyszczenie, oświecenie i zjednoczenie. Koncepcja Dionizego pojawiła się ponownie w Ix wieku u Jana Szkota Eriugeny, a później wraz ze św. Bernardem z Clairvaux i Wilhelmem z Saint Thierry szeroko rozpowszechniła się w klasztorach cysterskich. Najsłynniejsze swoje sformułowanie otrzymała u św. Bonawentury m.in. w dziele De triplici via. Natomiast Jan Tauler, przedstawiciel dominikańskiej mistyki nadreńskiej, promując podział trójstopniowy, nadał mu nieco odmienny od przyjętego wówczas charakter, wyróżniając etapy: radości, opuszczenia i przebóstwienia ${ }^{50}$. Widać więc, że Underhill wpisuje się w klasyczną tradycję strukturyzacji procesu mistycznego, wzbogacając starożytne i średniowieczne propozycje np. koncepcjami mistyki karmelitańskiej św. Jana od Krzyża.

Aczkolwiek mistyka rozumiana jako proces konsekwentnego rozwoju miłości może wydawać się czymś bardzo efemerycznym, czysto subiektywnym i spontanicznym, to jednak nie wymyka się ona pewnym obiektywnym kryteriom oceny, które określają zasadnicze wyznaczniki jej rozwoju i sprawiają, że rozwój ten podlega weryfikacji. Underhill uczy, że każde zatem jednostkowe

${ }^{48}$ E. Underhill, The Mystics of the Church, dz. cyt., s. 26-27.

49 E. Underhill, The Essentials of Mysticism, dz. cyt., s. 33-41.

${ }^{50}$ Por. The Essential Writings of Christian Mysticism, ed. by B. McGinn, New York 2006, s. $149-180$. 
doświadczenie mistyczne trzeba widzieć w szerszym kontekście jako część czegoś większego, jako element, stopień, etap, punkt na linii rozwojowej procesu duchowego. Nawet jeżeli rozwój ten przynosi z sobą zjawiska o charakterze materialnym, to ich przyczyny i ostatecznego uzasadnienia należy zawsze szukać na płaszczyźnie duchowej.

\section{Problem autentyczności i jedności mistyki}

„Jak odróżnić lunatyka od wizjonera, histeryka od świętego, modlitwę myślną od autosugestii?" - pyta Underhill w jednym ze swoich tekstów ${ }^{51}$. Poszukując odpowiedzi, dochodzi do wniosku, że wiarygodne doświadczenie mistyczne musi spełniać dwa kryteria, którymi są: zgodność świadków (consensus of witness) oraz życiodajna moc (life-giving power). Innymi słowy, wiarygodność doświadczenia mistycznego należy rozpatrywać:

- w szerokim kontekście istotnej zgodności tak pomiędzy samymi mistykami, jak i zgodności mistyków z ogólnym zmysłem religijnym wspólnoty, do której należą;

- mając na względzie całość kontekstu egzystencjalnego, w którym miało ono miejsce ${ }^{52}$.

Autentyczna mistyka nie izoluje człowieka, nie odcina go od jego społecznych i historycznych korzeni ${ }^{53}$. Wyklucza jedynie wszelki ekscentryzm. Dlatego, pielęgnując trzeźwy realizm, autentyczna mistyka podkreśla potrzebę dobrego postępowania, żywi szacunek dla tradycji i jest nieufna wobec wszelkich przejawów pogoni za sensacją. Poza tym doświadczenie indywidualne jest wiarygodne, gdy wyrasta $\mathrm{z}$ doświadczenia zbiorowego danej społeczności. Każdy mistyk jest głęboko uwarunkowany swoim środowiskiem, swym duchowym dziedzictwem, swoją przeszłością i teraźniejszością. W związku z tym każda

${ }^{51}$ Por. E. Underhill, The Authority of Personal Religious Experience, w: Evelyn Underhill: Modern Guide..., dz. cyt., s. 119.

52 „Two such marks are surely of signal importance; (1) consensus of witness; (2) life-giving power. That is, our view of the authority attaching to mystical experience cannot be arrived at without considering (a) the comparison of any one message with the general religious sense of the Church: (b) the whole of the life into which that message came" (E. Underhill, The Authority of Personal Religious Experience, dz. cyt., s. 122).

${ }_{53} \mathrm{~W}$ tym kontekście Underhill przytacza znane stwierdzenie Ryszarda od św. Wiktora: „Nie uwierzę, że widzę przemienionego Chrystusa, jeżeli nie będzie z Nim Mojżesza i Eliasza, czyli moralnego prawa i tradycyjnego objawienia" (E. Underhill, The Authority of Personal Religious Experience, dz. cyt., s. 122). 
próba zrozumienia jego świadectwa musi koniecznie uwzględniać ten fakt ${ }^{54}$. Dla Underhill obraz mistyka jako niezależnego indywidualisty, gardzącego tradycją i zorganizowanym kultem jest bardzo iluzoryczny i nie znajduje gruntownego uzasadnienia $\mathrm{w}$ tradycji historycznej5. Mistyka pozbawiona zdroworozsądkowej oceny ze strony społeczności, w której się rozwija, ciąży zwykle ku ekstrawagancji ${ }^{56}$.

Obok swego rodzaju poprawności doktrynalnej równie ważne jest drugie kryterium autentyczności doświadczenia mistycznego, a mianowicie obecność pewnego rodzaju życiodajnej energii, która, stymulując, pociąga i przemienia tego, który je przeżył. Autentyczne doświadczenie Boga zawiera w sobie zawsze jakieś wezwanie, jakąś domagającą się spełnienia misję, powołuje do realizacji jakiegoś zadania, którego istotę stanowi pewien rodzaj służebnej miłości. Ten, który doświadcza owej mocy, wychodzi z takiego spotkania odmieniony bardzo konkretnie i wymiernie ${ }^{57}$. Innymi słowy, mistyka jest rzeczywistością dynamiczną i zawsze przynosi z sobą jakieś konkretne owoce w postaci konkretnych działań mających na względzie dobro drugich. Takich owoców próżno szukać na drzewie kwietystycznego odrętwienia.

Underhill stoi na stanowisku, że mistyka nie jest jedynie własnością chrześcijaństwa, lecz stanowi element wielu innych tradycji religijnych. „Klejnoty literatury mistycznej - zauważa - połyskują blaskiem owej intymnej i płomiennej miłości ku Bogu, która wykracza poza dogmatyczne sformułowania i zyskuje prawo obywatelstwa wśród mistyków wszelkich ras i wyznań" ${ }^{58}$. Źródłem tego poglądu jest przekonanie o absolutnej transcendencji Boga: „Ponieważ Bóg przekracza wszystkie ludzkie wyobrażenia i pojęcia, możliwa jest różnorodność doświadczeń mistycznych i wszystkie one są w jakiś sposób niekompletne i niecałkowite" 59 . Uzasadniając swoje przeświadczenie w tej materii, autorka ucieka się do oryginalnej metafory: „Zamiar ograniczenia prawdy mistyki do formuły jakiejkolwiek religii jest równie nietrafiony, jak utożsamianie wartości szlachetnego metalu z prasą, która zamienia go na monety. Mistycy

${ }^{54}$ Por. E. Underhill, The Mystics of the Church, dz. cyt., s. 17-19. Na podstawie tej opinii można by Underhill uznać za patronkę współczesnych kontekstualistów ze Stevenem Katzem na czele. Zob. więcej M. Kiwka, Doświadczenie mistyczne w ujęciu konstruktywistycznego kontekstualizmu S. T. Katza, „Roczniki Filozoficzne” 1 (2007), s. 159-188.

55 Por. E. Underhill, The Mystics of the Church, dz. cyt., s. 21.

${ }^{56}$ Por. E. Underhill, The Mystics of the Church, dz. cyt., s. 16.

57 Por. E. Underhill, The Authority of Personal Religious Experience, dz. cyt., s. 123-126.

${ }^{8}$ E. Underhill, Mysticism, dz. cyt., s. 86.

59 E. Underhill, The Mystics of the Church, dz. cyt., s. 13. 
używają różnych pras [...], ale złoto, z którego wybijane są monety, jest zawsze tym samym szlachetnym metalem, zawsze tym samym uszczęśliwiającym widzeniem Dobra, Prawdy i Piękna, które jest czymś jednym i jedynym. Stąd też trzeba zawsze umieć odróżnić substancję od przypadłości, pod postaciami których ją postrzegamy, substancja bowiem ma wartość absolutną, a nie wyznaniową" ${ }^{\text {. Un }}$ Underhill jest świadoma złożoności problemu i daje temu wyraz między innymi w następujących słowach: „Umysł, który wychodzi na spotkanie Boga, nie jest i nie może być czystą kartą. Dlatego też fakt, że doświadczenie to wyraża się w terminach określonej tradycji niewątpliwie ogranicza go, ale nie dyskredytuje, bo musi ono przybrać jakąś szatę pojęciową, inaczej wymknie się zupełnie jakiemukolwiek rozumieniu. Jednakże należy pamiętać, że różnica pomiędzy mglistym kontaktem ze światem duchowym a mniej czy bardziej symboliczną formułą, za pomocą której się go wyraża, polega na tym, że formuła może być modyfikowana lub z czasem może całkowicie utracić dla nas swoje znaczenie, a pomimo to nadprzyrodzona wartość, której była wyrazem, pozostanie nienaruszona"61.

Niezwykła i zadziwiająca - podkreśla autorka - jest zgodność świadectw istniejąca pomiędzy największymi mistykami. Odnosi się wrażenie, że - wprawdzie nieraz na różnych drogach i w różny sposób - mówią oni o jednej i tej samej rzeczywistości, która stała się przedmiotem ich doświadczenia. Ich relacje różnią się między sobą, ale sobie nie zaprzeczają ${ }^{62}$. Zmuszają do uznania, że doszli oni do głębszego rozumienia życia religijnego swoich wspólnot i że to życie, przenikając ich do głębi, stawało się dla nich wsparciem na drodze duchowego wzrastania. Jednakże w miarę ich postępu macierzyste wspólnoty zaczęły tracić na znaczeniu, aż wszystko osiągnęło poziom takiej jedności, w którym różnica między formą a treścią przeżyć niemal przestała się liczyćc ${ }^{63}$.

${ }^{60}$ E. Underhill, Mysticism, dz. cyt., s. 96.

${ }^{61}$ E. Underhill, The Authority of Personal Religious Experience, dz. cyt., s. 129.

${ }^{62}$ Por. E. Underhill, The Authority of Personal Religious Experience, dz. cyt., s. 122-123.

${ }_{3}$ Por. E. Underhill, The Authority of Personal Religious Experience, dz. cyt., s. 129-130. Pomimo otwartości i akceptacji okazywanej różnym tradycjom religijnym Underhill uznaje - z poszanowaniem dla indywidualnych przekonań i bez przyznawania jakiemukolwiek systemowi wierzeń religijnych wyłączności do posiadania prawdy - że jest faktem historycznym, iż w chrześcijaństwie mistyka wyraziła się w sposób najdoskonalszy. W chrześcijaństwie Underhill dostrzega i akcentuje szczególnie dwie prawdy wiary mające ogromny wpływ na rozumienie oraz interpretację doświadczenia mistycznego, a mianowicie prawdę o Trójcy Świętej oraz prawdę o wcieleniu. Por. E. Underhill, Mysticism, dz. cyt., s. 104. 
W swoich publikacjach Underhill posiłkuje się fragmentami pism mistyków pochodzących z różnych kultur i tradycji religijnych. W celu wykazania fundamentalnej jedności opisów ich doświadczeń autorka proponuje metodę dwustopniowej analizy ${ }^{64}$. Istotą pierwszego etapu jest porównanie opisów doświadczeń mistycznych ze zwróceniem szczególnej uwagi na elementy wspólne, założenia wynikające $\mathrm{z}$ tradycji i przyjętych koncepcji teologicznych oraz na wszystko to, co jest efektem bardziej lub mniej świadomego naśladownictwa. W ten sposób można ustalić swego rodzaju wspólny mianownik, czyli pewien zbiór istotnych twierdzeń łączących różne relacje. Drugi stopień postępowania polega na przełożeniu wyodrębnionych twierdzeń na język i terminologię psychologii. Tym sposobem możliwe staje się określenie ich miejsca i roli w psychice człowieka.

Problem jedności doświadczenia mistycznego doczekał się rozwinięcia i dyskusji szczególnie $\mathrm{w}$ drugiej połowie $\mathrm{xx}$ wieku, wraz z dynamicznym rozwojem religioznawstwa porównawczego, kwestia ta nadal pozostaje otwarta, by nie powiedzieć: filozoficznie nierozstrzygalna.

\section{Kontekst filozoficzny}

Chociaż - jak zostało wyżej powiedziane - mistyka nie jest teorią, jednak w celu głębszego i pełniejszego zrozumienia samej siebie musi się ona odwołać do jakiejś teorii lub zbudować takową na własny użytek. Zdarza się, że sam mistyk staje się filozofem lub teologiem, gdy podejmuje próbę zinterpretowania swoich doświadczeń za pomocą dostępnej mu terminologii filozoficzno-teologicznej $j^{65}$.

Dla Underhill właściwy kontekst filozoficzny i zarazem klucz interpretacyjny dla doświadczeń mistycznych stanowi zaproponowana przez Rudolfa Euckena i Henri Bergsona tzw. filozofia życia. Nie ujmuje ona bytu w kategoriach statycznego istnienia, lecz raczej jako proces stawania się pozostającego w nieustannym rozwoju, wolnego, spontanicznego i kreatywnego życia ${ }^{66}$. Z czasem

${ }^{64}$ Por. E. Underhill, The Essentials of Mysticism, dz. cyt., s. 30.

${ }^{65}$ Co ciekawe, jak zauważa Underhill, uprawianie swego rodzaju filozofii bądź teologii mistycznej dokonuje się zwykle w na bazie formalnego credo, wyznawanego przez konkretnego mistyka, który zwykle okazuje się bardziej posłusznym wyznawcą niż duchowym anarchistą. Por. E. Underhill, The Essentials of Mysticism, dz. cyt., s. 95.

${ }^{66}$ Por. E. Underhill, The Essentials of Mysticism, dz. cyt., s. 26-28. W artykule Bergson and the Mystics Underhill okazuje się wręcz entuzjastką filozofii francuskiego myśliciela. Por. E. Underhill, Bergson and the Mystics, w: Evelyn Underhill: Modern Guide..., dz. cyt., s. 47-6o. 
to jej przekonanie uległo pewnej ewolucji i 18 lat po pierwszym wydaniu dzieła Mysticism, w nocie do wydania dwunastego wyznaje, że gdyby pisała tę książkę jeszcze raz, oparłaby się raczej na poglądach filozofów, którzy starają się przywrócić współczesnemu myśleniu krytyczny realizm scholastyki ${ }^{67}$. Prawdopodobnie na tę zmianę jej myślenia miał wpływ Friedrich von Hügel, wybitny myśliciel katolicki działający w Anglii na przełomie xIx i xx wieku, który przez wiele lat był jej duchowym przewodnikiem ${ }^{68}$. W neoscholastyce, która przeżywała wówczas swój renesans, Underhill widziała zwłaszcza niepomierną wartość metafizyki. Z kolei w metafizyce dostrzegała przede wszystkim coś, co określiła mianem „umiarkowanego dualizmu” (limited dualism) lub "filozofii dwóch kroków” (two-step philosophy), czyli zasadniczej otwartości na podwójny, materialno-duchowy wymiar istnienia ${ }^{69}$. Należy jednak zauważyć, że przyjęcie i zaakceptowanie określonej perspektywy filozoficznej ma dla Underhill mimo wszystko ograniczone znaczenie. Daje ona bowiem wyraz przekonaniu, że mistyk ostatecznie przekracza kontekst filozoficzny. Bycie i stawanie się, wieczność i czas, transcendencja i immanencja, realność i pozór, jedność i wielość - te paradoksalne doświadczenia tworzą syntezę wyższego rzędu, która staje się udziałem mistyka, a nie filozofa. Toteż nawet najbardziej adekwatna koncepcja filozoficzna może stanowić dla mistyki jedynie odległy kontekst, szerokie ramy, pewien punkt wyjścia. Mistyk przez swoje doświadczenie przekracza kategorie intelektualne, zespalając na płaszczyźnie egzystencjalnej wszystko to, co na gruncie spekulacji filozoficznej jawiło się jako odległe i wykluczające się ${ }^{70}$.

\section{Elementy struktury antropologicznej}

Z wyżej zaprezentowanych rozważań Underhill wyłania się określona koncepcja człowieka jako podmiotu doświadczenia mistycznego. Człowiek jawi się - by użyć tu określenia samej autorki - jako istota dwuśrodowiskowa

${ }^{67}$ Por. E. Underhill, Mysticism, dz. cyt., s. 43.

${ }^{68}$ Wkładem Fiedricha von Hügla w rozwój teorii mistyki jest między innymi jego dzieło The Mystical Element of Religion: As Studied in Saint Catherine of Genoa and Her Friends, LondonNew York 1909.

${ }^{69}$ Por. E. Underhill, Mysticism, dz. cyt., s. 43. Underhill upatrywała natomiast filozoficzne zagrożenia mistyki we wszelkiego typu pobożnych monizmach i naturalizmach.

${ }^{70}$ Por. E. Underhill, Mysticism, dz. cyt., s. 41. 
$(\text { amphibious })^{71}$. Jego egzystencja rozgrywa się jednocześnie w kontekście tego, co zmysłowe, historyczne, naturalne, przygodne, oraz pośród tego, co duchowe, ponadczasowe, nadprzyrodzone, absolutne ${ }^{72}$. W takim ujęciu staje on przed możliwością jednoczesnego rozwoju w dwóch, $\mathrm{z}$ pozoru tylko przeciwnych, kierunkach. Z jednej strony może jednoczyć się ze światem, z którego wyrasta i w którym rozwija się jego własne życie, $\mathrm{z}$ drugiej zaś ma możliwość przekraczania tego, co zmysłowe, i wchodzenia w kontakt z rzeczywistością duchową, czy wręcz „doświadczania” Boga ${ }^{73}$. Służy temu całe wyposażenie jego jestestwa, cała struktura antropologiczna, która w pewien sposób uzasadnia i zarazem wyjaśnia owo mistyczne „dzianie się,, którego człowiek staje się podmiotem. Underhill wymienia skrupulatnie zasadnicze elementy tej struktury:

A. Świadomość ludzka ma podwójny charakter i dzięki temu ma możność funkcjonowania na dwóch poziomach: powierzchniowym (świadomym), związanym z materią, oraz głębokim, z natury niedostępnym, pozostającym w bezpośredniej, choć nieuświadomionej relacji do Absolutu ${ }^{74}$.

B. W obszarze ludzkiej jaźni (świadomości powierzchniowej) wyróżniają się trzy dynamizmy: emocje oraz intelekt i wola ${ }^{75}$. Spośród nich prymat - zdaniem Underhill - przysługuje emocjom, których moc uruchamia skomplikowany mechanizm myślenia i działania, zwłaszcza wobec świata transcendentnego ${ }^{76}$. W tej perspektywie mistyka staje się sprawą serca, gdzie miłująca intuicja, emocjonalna pasja jest czymś o wiele bardziej efektywnym niż argumenty dialektyczne.

C. Życie w podstawowym swoim wyrazie przybiera dwie uzupełniające się formy: conation, czyli aktywność skierowana na zewnątrz (otwarte, energiczne działanie, dynamiczny impuls do zrobienia czegoś fizycznie, umysłowo

${ }^{71}$ Por. E. Underhill, Mysticism, dz. cyt., s. 34. W tekście Underhill opublikowanym w 1930 roku znajduje się ciekawy fragment mówiący o naturze człowieka. Warto przytoczyć go w oryginalnym brzemieniu: „It is a platitude that man is amphibious, a creature of the borderland. He cannot be explained in physical terms alone, or spiritual terms alone; but partakes of both worlds. I but, like many other so-called platitudes, this one conveys a stupendous truth which is seldom fully realized by us: the truth of our unique status, our capacity for God" (E. Underhill, God and Spirit, w: Evelyn Underhill: Modern Guide..., dz. cyt., s. 184).

${ }^{72}$ Por. E. Underhill, Our Two-Fold Relation to Reality, w: Evelyn Underhill: Modern Guide..., dz. cyt., s. 164 .

${ }_{73}$ Por. E. Underhill, Mysticism, dz. cyt., s. 35-36.

74 Por. E. Underhill, Mysticism, dz. cyt., s. 67.

75 Por. E. Underhill, Mysticism, dz. cyt., s. 67.

${ }^{76}$ Por. E. Underhill, Mysticism, dz. cyt., s. 47, 67. 
lub duchowo), oraz cognition, czyli dokonujące się w obszarze podmiotu poznanie (wewnętrzna świadomość, bierna wiedza o czymś). Podczas gdy pierwsza forma, $\mathrm{z}$ natury dynamiczna, jest efektem działania woli stymulowanej emocjami, to druga, $\mathrm{z}$ natury swej bierna, należy do sfery intelektu. Te dwie formy odpowiadają dwóm istotnym aspektom istnienia: stawaniu się i byciü ${ }^{77}$.

D. Ani działanie, ani poznawanie, których przedmiot stanowi naturalna egzystencja umieszczona w czasoprzestrzeni, nie są zdolne do ustanowienia jakiejkolwiek relacji z Absolutem. Sfera świadomości, gdzie wola i intelekt manifestują swoją obecność, jest zdeterminowana całkowicie światem wrażeń zmysłowych. Relacje mistyków wskazują na istnienie bardziej zaawansowanej władzy, należącej do głębszych i normalnie nieuświadomionych pokładów osobowości. Władza ta stanowi pierwszorzędny element doświadczenia mistycznego i pozostaje w żywotnym odniesieniu do świata transcendentnego. W literaturze mistycznej ów tajemniczy obszar określa się często mianem „centrum”, „skarbca”, „fundamentu”, „iskry”, „dna” lub „szczytu duszy”. Rozumie się przez to rodzaj osobowej nieskończoności, swoistą granicę, na której ludzka egzystencja styka się z boskim istnieniem i gdzie znajduje swój fundament. Tam też należy szukać uzasadnienia mistycznych wyzwań ludzkości ${ }^{78}$.

E. Pewne działania, do których należą między innymi akty kontemplacji, mogą doprowadzić do przemiany świadomości. Polega ona na takim poszerzeniu pola percepcji, że umożliwia ono wynurzenie się na powierzchnię świadomego istnienia owego głębszego „ja”, które czyni człowieka bytem mistycznym. Następuje wówczas ustanowienie bezpośredniej relacji z osobową Transcendencją. W powstałej wówczas więzi miłość i poznanie stają się jednością. Pomimo unifikacji osobowości i jej zjednoczenia z Absolutem, nie dochodzi jednakże do jej unicestwienia, lecz do przemiany i do

77 Por. E. Underhill, Mysticism, dz. cyt., s. 46-47, 67.

${ }_{78}$ Por. E. Underhill, Mysticism, dz. cyt., s. 49-52, 67. „[...] the mystics' claim that in their ecstasies they change the conditions of consciousness, and apprehend a deeper reality which is unrelated to human speech, cannot be dismissed as unreasonable. Do not then confuse that surface-consciousness which man has trained to be an organ of utility and nothing more - and which therefore can only deal adequately with the "given» world of sense - with that mysterious something in you, that ground of personality, inarticulate but inextinguishable, by which you are aware that a greater truth exist. This truth, whose neighborhood you feel, and for which you long, is Life. You are in it all the while, «like a fish in the sea, like a bird in the air» [...]" (E. Underhill, Mysticism, dz. cyt., s. 31). 
podporządkowania ${ }^{79}$. Mogłoby się wydawać, że przebieg tego złożonego procesu jest jedynie owocem wysiłku i konsekwentnego działania człowieka. Jednakże autorka z całym przekonaniem stwierdza, że zasadniczą przyczyną sprawczą jest tutaj Bóg działający w głębinach ludzkiej duszy, a cała mistyka i to wszystko, co ze sobą przynosi, jest następstwem daru, który w teologii zwykle określa się pojęciem łaski ${ }^{80}$.

Underhill konsekwentnie uznaje dwuwymiarowy charakter osobowości za podstawowy dogmat antropologii mistycznej. Świadomość człowieka funkcjonuje na dwóch poziomach: powierzchniowym - związanym z materią, oraz głębokim, $\mathrm{z}$ natury niedostępnym, pozostającym $\mathrm{w}$ bezpośrednim i nieuświadomionym odniesieniu do Absolutu. W tej perspektywie istota procesu mistycznego polega na doprowadzeniu do takiej przemiany, aby to, co skrywane dotychczas poza obszarem świadomości, mogło ukazać się w jej pełnym świetle, rozwijając w człowieku ową transcendentną władzę (transcendental faculty), owe „oko duszy”, patrzące daleko poza horyzont materialności ${ }^{81}$. Przemiana taka stwarza możliwość percepcji boskiej rzeczywistości w niezwyczajnych warunkach i pod niezwykłymi postaciami ${ }^{82}$.

Autorka ze szczególnym znawstwem odwołuje się do ówczesnych koncepcji psychologicznych. Nieobce są jej także poglądy, które sklasyfikowane pod ogólną nazwą modernizmu zostały potępione przez papieża Piusa $\mathrm{x} w \mathrm{w}$ dekrecie Lamentabili sane exitu oraz w encyklice Pascendi Dominici gregis. Zresztą wspomniany wyżej von Hügel, który w życiu duchowym i intelektualnym Underhill odegrał doniosłą rolę, był w Anglii jednym z promotorów tego rozwijającego się pod wpływem nauk eksperymentalnych nowego spojrzenia na wiarę $\mathrm{i}$ tradycję. Czy jednak zaprezentowane dotychczas poglądy pozwalają określić Underhill mianem propagatorki teorii modernistycznych?

Bez wątpienia w tzw. modernizmie dostrzegała ona szansę dialogu religii z ówczesną nauką. Fakt zakwestionowania przez Stolicę Apostolską koncepcji modernistycznych stał się dla niej osobiście jedną z przyczyn odstąpienia od zamiaru przyjęcia chrztu w Kościele katolickim. Brak jednakże jednoznacznych przesłanek merytorycznych, by jej poglądy na naturę mistyki określić

79 Por. E. Underhill, Mysticism, dz. cyt., s. 67-68.

8o „The emphasis lies on God, the Fact of all Facts, and His action; not on the partial experiences of our uneven, tentative and many-leveled consciousness, still so uncertain in its grasp of all that lies beyond the world of sense" (E. Underhill, God and Spirit, dz. cyt., s. 183).

${ }^{81}$ Por. E. Underhill, Mysticism, dz. cyt., s. 55.

${ }^{82}$ Por. E. Underhill, Mysticism, dz. cyt., s. 65. 
np. terminem immanentyzmu religijnego, aczkolwiek akcentowanie przez nią wiodącej roli uczuć lub znaczenia aktów „podświadomych percepcji duchowych" (subconscious spiritual perceptions) ${ }^{83}$ mogłoby sugerować bliskie pokrewieństwo z poglądami Rudolfa Otto ogłoszonymi w jego słynnym dziele Das Heilige. Über das Irrationale in der Idee des Göttlichen und sein Verhältnis zum Rationalen ${ }^{84}$. Również koncepcja nieuświadomionych głębin ludzkiej jaźni mogłaby świadczyć o związkach $\mathrm{z}$ freudowskim pojęciem podświadomości, jednakże - jak się wydaje - to nie psychoanaliza, lecz tradycja mistyki chrześcijańskiej stanowi jej właściwy kontekst. Zdaniem Underhill ówczesna psychologia, w swojej doktrynie o osobowości podprogowej, uznając istnienie życia psychicznego ponad polem świadomości i poniżej niego, jedynie potwierdza odwieczne intuicje mistyków ${ }^{85}$. Zresztą nie bez ironii autorka stwierdza, że współcześni jej psychologowie nazbyt łatwo redukują główne fenomeny doświadczenia religijnego do działania „nieświadomości” (unconsciousness), widząc w niej zawoalowaną chęć zaspokojenia tłumionych pragnień człowieka. „Nieświadomość” okazuje się tu wygodną kategorią, która w sposób nie do końca uprawniony łączy ze sobą różnorodność przeżyć, sił i dynamizmów działających w człowieku ${ }^{86}$. Byłoby zatem zbytnim uproszeniem określenie poglądów Underhill jako modernistycznych. Faktem jednak pozostaje, że poszukując instrumentarium interpretacyjnego, wchodzi ona $\mathrm{z}$ modernizmem w dialog przybierający czasami charakter polemiki i sporu, a czasami wspólnej eksploracji bogactwa przeżyć przekazanych w relacjach mistyków.

\section{Wizja przyszłości mistyki}

Mistycy są duszą i niezawodnym probierzem żywotności każdej wspólnoty religijnej. Zachowują w niej niezachwianą świadomość Boga i wytrwałą pamięć o Jego obecności w każdym człowieku i pomiędzy wszystkimi ludźmi. Utrzymują bliskie i pełne miłości poczucie Bożej bliskości, bez którego każda instytucja religijna szybko staje się czymś bezdusznie zimnym ${ }^{87}$. Tworzą w jej ramach przestrzeń modlitwy, gdzie człowiek odnajduje odpowiednie warunki,

${ }^{83}$ E. Underhill, Mysticism, dz. cyt., s. 91.

${ }^{84}$ Wydanie polskie: R. Otto, Świętość. Elementy irracjonalne w pojęciu bóstwa i ich stosunek do elementów racjonalnych, tłum. B. Kupis, Wrocław 1993.

${ }^{85}$ Por. E. Underhill, Mysticism, dz. cyt., s. 52-53.

${ }^{86}$ Por. E. Underhill, Mysticism, dz. cyt., s. 52.

${ }^{87}$ Por. E. Underhill, The Mystics of the Church, dz. cyt., s. 10-11. 
w których może otworzyć się na nieskończoność, kształtować i umacniać wrodzoną zdolność do uczestnictwa w wieczności, wychowywać i wyostrzać ów zmysł duchowy, bez którego ludzkie życie staje się płaskie, płytkie i niepewne swoich własnych celów ${ }^{88}$. Dlatego przyszłość mistyki w jakimś stopniu określa kierunek rozwoju samej ludzkości. Podejmując kwestię przyszłości mistyki po straszliwym doświadczeniu pierwszej wojny światowej ${ }^{89}$, a przed jeszcze straszliwszymi latami zmagań totalitaryzmów, Underhill uzależniła ją od następujących czynników:

- od pojawienia się wielkich widzących, którzy osobiście poznawszy smak nieskończoności, mogą o niej zaświadczyć,

- od ogólnej atmosfery społecznego zapotrzebowania na coś trwalszego niż doraźnie konsumowana przyjemność,

- od powstawania centrów żywej duchowości otwierającej człowieka na transcendentny wymiar istnienia ${ }^{90}$.

Rozwojowi autentycznej mistyki, w przekonaniu autorki, najbardziej sprzyja atmosfera mocnego poczucia obowiązku, klimat moralnej powinności kształtowanej wzniosłym kodeksem zasad, wizja życia inspirowanego jasno określonymi prawdami wiary religijnej, zdolnej utrzymać właściwy kierunek rozwoju, szczególnie w czasie zawirowań i kryzysów. Poza tym historia uczy, że okresy renesansu mistyki następują zwykle po czasie zagubienia wartości, wielkiego ubóstwa duchowego i krwawych konfliktów, oraz że odrodzenie duchowe pojawia zwykle w instytucjonalnych ramach wielkich historycznych Kościołów i wspólnot religijnych. W nich mistyka owocuje odnowioną i zintensyfikowaną komunią ze światem duchowym, a poprzez nie tym darem promieniuje na cały świat. Mistyka bowiem, pozbawiona swego instytucjonalnego wyrazu, wykazuje tendencję do udziwnień i sentymentalizmu. Jako dusza religii, podobnie jak dusza ludzka, potrzebuje ona ciała (wspólnoty, społeczności), by spełnić swoje przeznaczenie. A przeznaczenie to - jak zaznacza Underhill - wbrew pozorom nie jest indywidualne, lecz społeczne: „ukazać innym tchnące świeżością obszary ducha, udostępnić drugim niespotykaną obfitość życia w Bogu"91.

${ }^{88}$ Por. E. Underhill, Our Two-Fold Relation to Reality, dz. cyt., s. 168.

${ }^{89}$ Swój tekst pt. The Future of Mysticism Underhill opublikowała w 1918 roku.

${ }^{\circ}$ Por. E. Underhill, The Future of Mysticism, dz. cyt., s. 64.

${ }^{91}$ E. Underhill, The Future of Mysticism, dz. cyt., s. 65-66. 


\section{Podsumowanie}

Koncepcja mistyki obecna w twórczości Evelyn Underhill wyrasta zasadniczo $\mathrm{z}$ tradycji chrześcijańskiej, ma więc charakter teistyczny i zakłada bezpośrednie odniesienie do osobowego Boga. Autorka konsekwentnie uznaje duchowy wymiar ludzkiej egzystencji, realizujący się na wielu poziomach osobowego istnienia. Pomimo swoich zdecydowanie chrześcijańskich inspiracji czerpie ona także z doświadczeń innych tradycji religijnych, zwłaszcza monoteistycznych. Sięga również do koncepcji i pojęć wypracowanych przez współczesne jej nauki, szczególnie w obszarze psychologii. W jej rozumieniu mistyka $\mathrm{w}$ sensie szerokim jest prostym przekonaniem wiary o istnieniu rzeczywistości duchowej. W sensie ścisłym natomiast jest bezpośrednim doświadczeniem Boga. Jako taka ma charakter praktyczny i egzystencjalny, jest określoną umiejętnością - sztuką bycia w relacji do Absolutu. Umiejętność ta kształtuje się w duchowym i głęboko przeobrażającym procesie rozwoju miłości, której kresem jest całkowite zjednoczenie z Bogiem. Z punktu widzenia psychologicznego proces mistyczny, angażując człowieka we wszystkich sferach jego egzystencji, prowadzi do poszerzenia pola świadomości, w którym pojawiają się dotychczas nieuświadomione elementy struktury antropologicznej. Ich istnienie stanowi ontyczną podstawę odniesienia osoby ludzkiej do Boga i fundament ich wzajemnej komunii. Bezinteresowna miłość, stanowiąca rację istnienia i najgłębszą istotę mistyki, wyklucza cele teoretyczno-poznawcze, jak również wszelkie praktyki magiczne. Pomimo że na mistykę składa się rozległe spectrum przeżyć, to jednak nie jest ona czymś jedynie subiektywnym i spontanicznym. Underhill określa konkretne etapy rozwoju duchowego i podaje w miarę ścisłe kryteria ich autentyczności. Pozostają one $\mathrm{w}$ zgodzie $\mathrm{z}$ wielowiekową tradycją chrześcijańską $\mathrm{w}$ tym względzie. Stojąc na stanowisku jedności doświadczenia mistycznego, znajdującego swe uzasadnienie w istotnej zgodności relacji mistyków należących do różnych tradycji, autorka zwraca uwagę na kontekst historyczny, społeczny i religijny, podkreślając jego różnicujący wpływ na kształt konkretnych przeżyć mistycznych. W tej perspektywie za niezwykle wartościowe uznaje istnienie ram religii instytucjonalnej, w jakich zwykle mistyka się rozwija. Jej refleksje, wyrosłe z namysłu nad dziejami duchowości, pozostają aktualne także i dziś, inspirując i wyznaczając kierunki poszukiwań odpowiedzi na pytania stawiane pod adresem mistyki przez czas obecny. 


\section{Abstrakt}

W świecie anglojęzycznym I połowy xx wieku Evelyn Underhill (1875-1941) była jedną z najbardziej poczytnych autorek, piszących o religii i życiu duchowym, a szczególnie o mistyce chrześcijańskiej. Ukazanie zasadniczych elementów jej teorii mistyki stanowi zasadniczy cel niniejszego przedłożenia. Jego realizację otwiera przedstawienie wypracowanego przez nią pojęcia mistyki i jej zasadniczych charakterystyk. Omówienie etapów procesu mistycznego, problemu autentyczności oraz jedności doświadczenia mistycznego łącznie $z$ kontekstem filozoficznym i strukturami antropologicznymi, które autorka wykorzystuje w swoich analizach - stanowi tematykę dalszej części opracowania. Całość zamyka niezwykle inspirująca wizja mistycznej przyszłości rodzaju ludzkiego, jaką znajdujemy w publikacjach tej anglikańskiej pisarki.

\section{SŁOWA KLUCZOWE}

Evelyn Underhill, filozofia religii, mistyka, doświadczenie mistyczne

\section{Abstract}

\section{Evelyn Underhill's Understanding of Mysticism}

In the English-speaking world of the first half of the twentieth century Evelyn Underhill (1875-1941) was one of the most widely read writers on religion and spiritual practice, in particular on Christian mysticism. The paper aims at Underhill's understanding of mysticism. Beginning with the presentation of the concept of mysticism and its main characteristics, the classification of the phases of the mystical process, through the problem of the authenticity and unity of the mystical testimonies, including the philosophical context of her thought and anthropological structures used in her analysis - there are presented here the fundamental features of Underhill's theory of mysticism. The whole supplements her inspiring vision of the mystical future of the mankind.

\section{KEYWORDS}

Evelyn Underhill, philosophy of religion, mysticism, mystical experience

\section{BIBLIOGRAFIA}

Armstrong C. J. R., Evelyn Underhill (1875-1941). An Introduction to Her Life and Writings, Grand Rapids 1976.

Callahan A., Evelyn Underhill: Spirituality for Daily Living, Lanham 1997. 
Cropper M., The Life of Evelyn Underhill, New York 1958.

The Essential Writings of Christian Mysticism, ed. B. McGinn, New York 2006.

Evelyn Underhill: Modern Guide to the Ancient Quest for the Holy, ed. D. Greene, Albany 1988.

Greene D., Evelyn Underhill: Artist of the Infinite Life, Notre Dame 1998.

Hügel von F., The Mystical Element of Religion: As Studied in Saint Catherine of Genoa and Her Friends, London-New York 1909.

James W., Doświadczenia religijne, tłum. J. Hempel, Kraków 2001.

Kiwka M., Doświadczenie mistyczne w ujęciu konstruktywistycznego kontekstualizmu

S. T. Katza, „Roczniki Filozoficzne” 1 (2007), s. 159-188.

Kiwka M., Mistyczne implikacje Arystotelesowskiej koncepcji miejsca naturalnego, „Wrocławski Przegląd Teologiczny” 2014 nr 2, s. 7-19.

Kiwka M., Mistycyzm integralny w ujęciu Bernarda McGinna, „Roczniki Filozoficzne” 1 (2017), s. 23-42.

Otto R., Świętość. Elementy irracjonalne w pojęciu bóstwa i ich stosunek do elementów racjonalnych, tłum. B. Kupis, Wrocław 1993.

Ramsey M., Allchin A. M., Evelyn Underhill. Two Centenary Essays, Oxford 1977.

Underhill E., The Authority of Personal Religious Experience, w: Evelyn Underhill: Modern Guide to the Ancient Quest for the Holy, ed. D. Greene, Albany 1988, s. 117-132.

Underhill E., Bergson and the Mystics, w: Evelyn Underhill: Modern Guide to the Ancient Quest for the Holy, ed. D. Greene, Albany 1988, s. 47-6o.

Underhill E., The Mystic as Creative Artist, w: Understanding Mysticism, ed. by R. Woods, Garden City 1980, s. 400-414.

Underhill E., Mysticism. The Nature and Development of Spiritual Consciousness, Oxford 2002.

Underhill E., The Mystics of the Church, Cambridge 1925.

Underhill E., Defense of Magic, w: Evelyn Underhill: Modern Guide to the Ancient Quest for the Holy, ed. D. Greene, Albany 1988, s. 31-46.

Underhill E., The Essentials of Mysticism, w: Understanding Mysticism, ed. by R. Woods, Garden City 1980, s. 26-41.

Underhill E., Future of Mysticism, w: Evelyn Underhill: Modern Guide to the Ancient Quest for the Holy, ed. D. Greene, Albany 1988, s. 61-67.

Underhill E., God and Spirit, w: Evelyn Underhill: Modern Guide to the Ancient Quest for the Holy, ed. D. Greene, Albany 1988, s. 177-190.

Underhill E., Our Two-Fold Relation to Reality, w: Evelyn Underhill: Modern Guide to the Ancient Quest for the Holy, ed. D. Greene, Albany 1988, s. 161-176.

Underhill E., Practical Mysticism, New York 1915. 